\title{
Fruit flies: disinfestation, techniques used, possible application to mango
}

\author{
Marie-Noëlle DUCAMP Collin ${ }^{\star a}$, Cécile ARNAUD $^{b}$, Valérie KAGY ${ }^{c}$, Christian DIDIER $^{a}$
}

a Cirad-Persyst, TA B-95 / 16, 34398 Montpellier Cedex 5,

France

ducamp@cirad.fr, christian.didier@cirad.fr

b CNEARC, 1101 Av Agropolis, BP 5098, 34033 Montpellier

Cedex 1, France

${ }^{c}$ Institut agronomique neo-calédonien, Centre de recherches fruitières de Pocquereux, La Foa, Nouvelle-Calédonie kagy@iac.nc

\section{Fruit flies: disinfestation, techniques used, possible application to mango.}

Abstract - Introduction. The methods of fruit disinfestation against fruit flies use processes (physical methods) which differ according to the export country and fruit which must be disinfested. The term definitions are made clear and the various treatments are presented. Heat treatments. For mango, treatments usable for disinfestation can only utilize heat, because of the strong sensitivity of this fruit to cold temperatures. The heat treatments in general consist of using an immersion in hot water by a system of batches or an uninterrupted bath. These treatments are then followed or not by a fruit fast cooling which can be carried out by ventilation (cold air) or hydrocooling (water). Heat can also be obtained by use of forced hot air or hot vapor, because a higher temperature than $45^{\circ} \mathrm{C}$ kills fly eggs and larvae. Microwave treatments. The use of microwaves is also a technique which makes it possible to increase the temperature in the fruit heart. Irradiation. The last possible solution is the use of irradiation, which uses a principle different from the preceding treatments. Conclusion. In comparison with the most current treatments (vapor heat treatment and forced hot-air treatment), the hot water treatment has many advantages: it is easy to implement, it is quick, it kills surface parasitic organisms, it makes it possible to clean the fruit surface and its cost only corresponds to approximately $10 \%$ of the cost of one vapor heat treatment. It would thus be recommended for mango disinfestation.

France / fruits / Mangifera indica / tephritidae / stored products' pest control / heat

\section{Mouche des fruits : désinfestation, techniques utilisées, application possible à la mangue.}

Résumé - Introduction. Les méthodes de désinsectisation des fruits pour les infestations de mouches de fruits font appel à des procédés (méthodes physiques) qui diffèrent selon le pays d'exportation et selon le fruit qui doit être désinsectisé. Les définitions des termes sont reprises et les différents traitements sont présentés. Traitements à la chaleur. Pour la mangue, les traitements utilisables pour la désinsectisation ne peuvent faire intervenir que la chaleur en raison de la forte sensibilité de ce fruit au froid. Les traitements à la chaleur consistent en général à utiliser une immersion dans l'eau chaude par système de batch ou en continu. Ces traitements sont ensuite suivis ou non d'un refroidissement rapide des fruits qui peut être réalisé par ventilation (air froid) ou par bydrocooling (eau). La chaleur peut aussi être obtenue par utilisation d'air chaud forcé ou de vapeur chaude car une température supérieure à $45^{\circ} \mathrm{C}$ tue les oufs et les larves des mouches. Traitements aux micro-ondes. L'emploi de micro-ondes est aussi une technique permettant d'augmenter la température à cour des fruits. Irradiation. La dernière solution envisageable est l'utilisation de l'irradiation qui met en jeu un principe différent des précédents. Conclusion. En comparaison avec les traitements les plus courants (traitement à la vapeur d'eau chaude et traitement à l'air chaud forcé), le traitement par trempage en eau chaude a de nombreux avantages : il est facile à mettre en œuvre, il dure peu longtemps, il détruit des organismes parasites de surface, il permet de nettoyer la surface des fruits et son coût correspond à environ $10 \%$, seulement, du coût d'un traitement à la vapeur d'eau chaude. Il serait donc préconisé pour la désinfestation des mangues.

France / fruits / Mangifera indica / tephritidae / lutte antiparasite en entreposage / chaleur
Fruits, 2007, vol. 62, p. 223-236 (C) 2007 Cirad/EDP Sciences All rights reserved DOI: $10.1051 /$ fruits:2007018 www. fruits-journal.org

RESUMEN ESPAÑOL, p. 236 


\section{Introduction}

The international transport of fruit, a potential host of fruit fly, has been the subject of a lot of research aiming at determining quarantine techniques intended to avoid the development of such insects in geographical areas which are free of them.

Applied in a precise and rigorous way, quarantine methods have reduced the development of fruit fly (Tephrididae). However, with the increase in transport and commercial exchange, quarantine barriers have become difficult to maintain and new flies are very often introduced; since 1980, a great number of them has been especially observed in the United States. The list of the flies thus listed is long: Bactrocera invadens, Ceratitis capitata (Mediterranean fruit fly), Ceratitis rosa (Natal fruit fly), Bactrocera cucurbitae (melon fruit fly), Bactrocera dorsalis (oriental fruit fly), Bactrocera zonata (peach fruit fly), Anastrepha suspensa and Dacus bactrocera latifrons (Malaysian fruit fly).

The plant protection authorities of most of the importing countries accept various procedures using physical or chemical treatments, or a combination of both. However, the prohibition of ethylene dibromide, which began in the United States and which is currently spreading on an international scale, as well as the restriction of methyl bromide use as quarantine treatment by fumigation, involve the development and the application of substitute treatments for pollutant gases. Now, research efforts are relating to the application of physical treatments such as heat or cold, which are likely to be more expensive and more difficult to implement than the gas treatments.

An international consensus does not exist on the level of the necessary quarantine degree applicable to the products presenting contamination risks by fruit flies. Many imported and marketed tropical fruits do not have their own treatments of disinfestation.

In this field, the most immediate prospect would relate to quarantine treatments or to systems making it possible to open or maintain the tropical fruit export and market through the quarantine barriers.

\section{Terminology regarding fruit quarantine}

Several terms describe the risk situation of fruit-bearing production with respect to its pests:

- A quarantine host corresponds to any tropical fruit, at one or more stages of its development, likely to be infested in the field and to become an insect or fungus development support.

- A quarantine treatment implies any action, or unit or multiple treatments, which can be applied for disinfesting tropical fruit hosts in order to ensure quarantine safety.

- A quarantine system is an approach system, which uses individual operational compounds, each one of them involving a reduction of the fruit infestation, or of the number of affected fruits, until quarantine completion.

- Quarantine safety implies a statistical degree of probability, which makes it possible to ensure that the quarantine treatments or systems are effective: after their action, the insects will not be able to be transported and to develop in the countries of arrival where they are not present.

The quarantine treatments are more difficult to develop if there are several developmental stages of the infesting organisms present on or in the fruits, because, as a preliminary, the most resistant stage to treatment has to be determined. For example, the "egg" and "chrysalis" stages can be more resistant to treatments by fumigation than the "larva" and "adult" stages because of their weaker metabolism and breathing. In addition, localization of the organism itself - whose developmental stages either are present on the fruit surface, or inside the fruit in the pulp, seed cavity or seed itself affects the quarantine-treatment type and severity or the system chosen for disinfesting the fruits. Thus, the developmental stages of insects present only on the fruithost surface are the most sensitive to the treatment because they are exposed to it; insects having stages developing inside the fruit host require more severe treatments because the products have to spread inside the fruit to cause their death. 
Insecticides such as dimethoate and fenthion integrated into immersion baths or vaporizations are used as postharvest disinfestation treatment against the banana fly, but the technique does not have a broad action spectrum. Even the compounds presenting close spectra, such as methoprene, a growth regulator causing fly death, mixed with waxes and applied to the fruit, is not commercially used for disinfestation treatments.

Thus, the future of pesticides in this field appears very limited because it would be necessary to find efficient compounds, which are approved. Their already prohibitory cost is greatly increased by the tests which would be necessary to obtain their accreditation; their development and their use are slowed down by the legislation concerning the pesticide residual levels in food products and additives.

In fact, the technologies of the quarantine treatments used today are a palliative to fumigation by pollutant gases. They include the fruit-host temperature increase or reduction above or below the limits of thermal resistance of the insect concerned. They can also utilize irradiation to kill or sterilize the insect in question.

To be accepted by the quarantine authorities of certain countries, treatments must present a probability of significant effectiveness, proving that they kill more than $99.9968 \%$ of the insects present. Such a "probatory" value would mean that only three individuals among 100000 individuals would be authorized to survive after a quarantine treatment.

Nevertheless, some other countries, including Japan, use a variation of this measurement, called "probit9", the concept of which does not authorize any insect survival in a population of 30000 infesting individuals.

\section{Heat treatments}

Heat treatments, based on the fact that a temperature higher than $45^{\circ} \mathrm{C}$ kills fly eggs and larvae, in general consist of treating fruit by forced hot air or hot vapor, or immersing them in warm water.
Relatively easy to apply, these treatments can be used against fungi or pests; they have the advantage of not leaving chemical residues. However, in certain cases, they have the disadvantage of causing damage to the fruits; this damage must be evaluated fruit by fruit.

\subsection{Immersion in warm water}

\subsubsection{Principle}

Immersion in warm water, also called hydrothermal treatment, uses warm water to increase the internal temperature of the product to be treated during a given time. Warm water is a good vector, which makes it possible to raise the skin temperature, then that of the fruit pulp, in a uniform way.

The time-temperature couple is variable according to the fruit and the parasite to be eliminated; warm-water immersions of perishable goods, to be officially approved and satisfactory against fruit fly in particular, must allow a rise in temperature in the fruit heart varying between $43.0^{\circ} \mathrm{C}$ and $46.7^{\circ} \mathrm{C}$, with durations ranging between $35 \mathrm{~min}$ and 90 min [1-12].

Treatment by warm-water immersion is successfully used to treat mangos infested by the Mediterranean fly and by other Anastrepha species before importation of fruit from Mexico, the Caribbean, Central America and South America (figure 1) into the United States.

Research carried out on mangos, which are relatively resistant-to-heat fruits, shows that the warm-water treatment can be approved in quarantine for mangos infested by immature flies [5-10, 12, 13].

\subsubsection{Batch system, also called "jacuzzi"}

Most of the systems used to treat fruit by immersion in warm water are of the batch type. During this process, fruit cases are loaded onto a platform which is itself plunged into an immersion tank, maintained at the desired temperature. After the processing time is completed, the cases are taken out. Identification by case marking makes it possible to follow up if there is a premature 

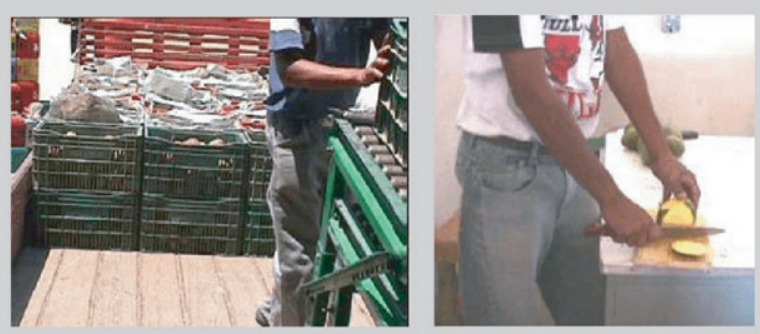

Unloading and control of mangos coming from orchards
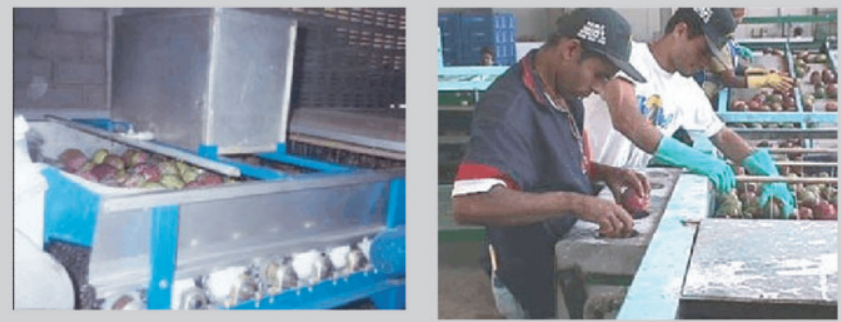

Peduncles cut during the fruit washing by sprinkling of a $0,5 \%$-unslaked lime (or detergent) solution

to neutralize latex and to eliminate dirt traces and plant health products leftovers

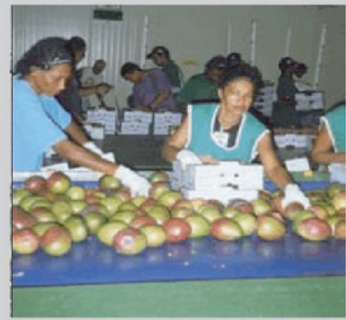

For Europe: fruits weighed and directly packed after a light hydrothermal treatment (smaller tank), passage under wax sprinkling, then brushing.

Only fruit without defects are selected

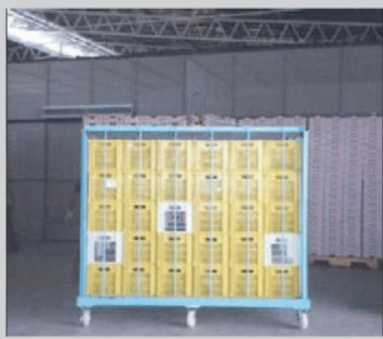

For USA: fruits graded by weight, put in plastic cases, then in cages (with a temperature probe)

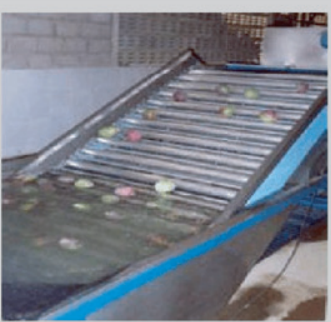

Cases directly emptied in the first rinsing water with more or less care

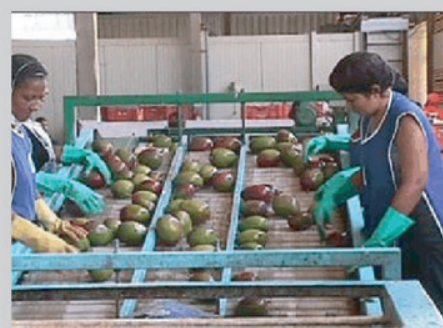

First screening of fruit for eliminating those with blow traces, burns (latex or sun), thrips traces, peduncular rot, visible collapses, mealy bugs, etc.

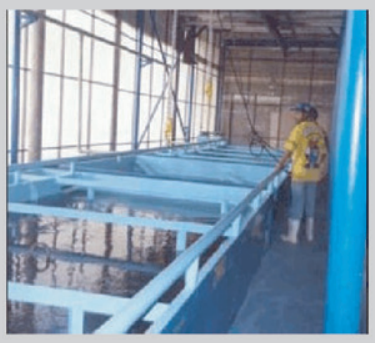

Cages put in tanks for hydrothermal treatment (wide tanks), followed or not (after a 30-min rest) by an hydrocooling
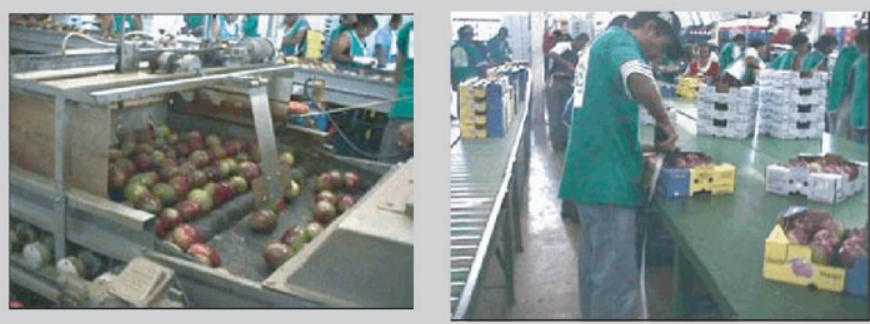

After an other ( 8 to 24$)$-h rest at ambient temperature, fruits are waxed and mechanically brushed before

being sorted by weights and packed by grades. Rejection of fruits with bad appearance (affected by treatment).

Cardboard box homogeneity depends on the competence of the worker
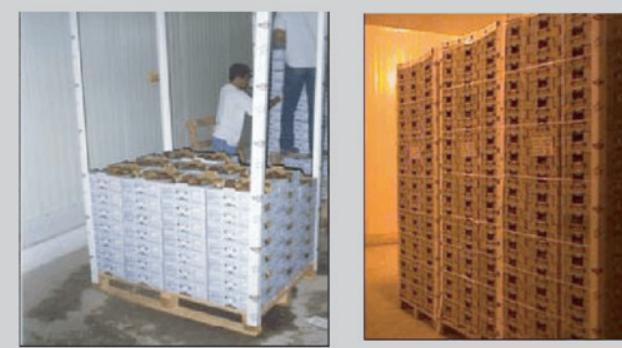

Cardboard boxes, piled up on 3 columns of 60 boxes ( 240 in all), are maintained by nylon wire, then stored in cooling tunnel at $10^{\circ} \mathrm{C}$ and $85 \%$ of ventilated humidity before expedition. Container is placed at exit of the cold room for loading. A mosquito net is tended to avoid the pest passage in the container during the loading

\section{Figure 1.}

Steps of mango packaging in

Brazil, integrating a warm-

water treatment step. 
exit out of the tank. However, there can be an electronic or different witness which actuates itself if a load leaves the bath too early, and which stops or blocks the system as long as the treatment is not finished.

\subsubsection{Uninterrupted system}

In the system of continuous immersion in warm water, the products to be treated are placed in cases on a mechanical conveyor which slowly moves from one end to another of a warm-water bath.

The speed of the conveyor is controlled so that fruits remain immersed during the desired time; the system requires instrumentation to control the speed of the conveyor.

A speedometer placed in the system makes it possible to check the speed of the conveyor drive belt and, at the same time, the duration and the temperature of the treatment; it can indicate when the system is moving or when it was stopped in the process of treatment.

Small sized fruit require an adaptation of the technique; this is why the conveyor system, the belt speed and the processing times must be adjustable. Thus, if the speed of the conveyor is constant, it is then necessary to be able to adapt the length of the immersed portion of the conveyor and the contact time determined for this specific category of fruits. In addition, it is necessary to avoid having a movement back and forth in the tank because of possible floating of the fruits.

Systems of this type, set up after the nineties, could have the disadvantage of causing mechanical damage to the fruits if they are not placed in baskets. In addition, the fruittreatment uninterrupted system has the disadvantage of occupying a greater space on the ground compared with an installation of the batch type.

According to the fruits, there can be variations in the species and the larva developmental stages of the insect controlled by these treatments. When circulation in the warm-water bath is correctly carried out through the fruit cases and when the necessary setting temperature is fast and uniform, this treatment allows a heat transfer [14]. The technique has the advantage of being able to control postharvest problems such as anthracnose and stem-end rot [13, 14,]. However, times and temperatures of warm-water treatment can damage the treated fruits, as certain symptoms observed on mangos show (table I).

\section{Table I.}

Description of damage caused to mangos by quarantine treatments (warm water, hot air or vapor heat) [33].

\begin{tabular}{|c|c|c|c|}
\hline Mango cultivar & Heat treatment & Heat injury & Reference \\
\hline Carabao & VHT $46{ }^{\circ} \mathrm{C}$ for $10 \mathrm{~min}$ & $\begin{array}{l}\text { Internal browning in inner mesocarp of ripe fruit; } \\
\text { white, starchy, tough lesions; fermented odor }\end{array}$ & [39] \\
\hline $\begin{array}{l}\text { Haden, Irwin, Kensington, Strawberry, } \\
\text { Tommy Atkins, }\end{array}$ & $\begin{array}{l}\text { HWT (42 to } 48){ }^{\circ} \mathrm{C} \text { for } \\
\text { 30-90 min }\end{array}$ & Skin scalding & {$[36]$} \\
\hline \multirow[t]{2}{*}{ Keitt } & $\begin{array}{l}\text { HWT } 46{ }^{\circ} \mathrm{C} \text { for } 90 \mathrm{~min} \\
\text { or HWT } 49^{\circ} \mathrm{C} \text { for } 60 \mathrm{~min}\end{array}$ & Darkened lenticels & [34] \\
\hline & $\begin{array}{l}\text { VHT } 46^{\circ} \mathrm{C} \text { for }(3 \text { to } 4) \mathrm{h} \\
\text { or VHT } 48^{\circ} \mathrm{C} \text { for } 5 \mathrm{~h}\end{array}$ & $\begin{array}{l}\text { Internal cavities formed near the seed } \\
\text { Surrounded by hard unripe tissue }\end{array}$ & [38] \\
\hline \multirow[t]{2}{*}{ Kensington } & $\begin{array}{l}\text { HWT } 48{ }^{\circ} \mathrm{C} \text { for }(7.5 \text { to } \\
30) \min \end{array}$ & $\begin{array}{l}\text { Skin scalding: uneven skin color development } \\
\text { with ripening; starch retention in the form } \\
\text { of layers and spots in ripe fruit; internal cavities }\end{array}$ & {$[35]$} \\
\hline & $\mathrm{HWT} 47^{\circ} \mathrm{C}$ for $25 \mathrm{~min}$ & $\begin{array}{l}\text { Internal cavities; } \\
\text { starchy regions retained in ripened mesocarp }\end{array}$ & {$[37]$} \\
\hline \multirow[t]{2}{*}{ Tommy Atkins } & $\begin{array}{l}\text { HWT } 46{ }^{\circ} \mathrm{C} \text { for } 120 \mathrm{~min} \\
\text { or HWT } 49^{\circ} \mathrm{C} \text { for } 60 \mathrm{~min}\end{array}$ & Darkened lenticels & [34] \\
\hline & FHAT $51.5^{\circ} \mathrm{C}$ for $125 \mathrm{~min}$ & Peel pitting & [23] \\
\hline
\end{tabular}


We have to note that:

- in Central America, the treatment consists of a $46.1{ }^{\circ} \mathrm{C}$ steeping carried out either in a tank, or in an uninterrupted system, for (65 to 90 ) min;

- the protocol of disinfestation by warm water is approved for the admission into the United States for mangos from Mexico, Puerto Rico, Virgin Islands and the West Indies;

- generally, fruit of lengthened type of less than $375 \mathrm{~g}$ are treated at $46.1^{\circ} \mathrm{C}$ for less than $65 \mathrm{~min}$; for fruit weights ranging between (375 and 570) g, a temperature of $46.1^{\circ} \mathrm{C}$ is maintained for $75 \mathrm{~min}$;

- these treatments can cause rather significant damage on the fruit skin (table I).

According to the international standards, it would be necessary to treat fruits for $20 \mathrm{~min}$, at $48^{\circ} \mathrm{C}$. However, tests carried out on five mango varieties showed that a more than 90-min treatment would prove to be necessary. A steeping longer than $30 \mathrm{~min}$ would cause $100 \%$ pest mortality.

Fruits maintained at $25^{\circ} \mathrm{C}$ after treatment are analyzed according to acceptance criteria, which can be their weight loss within the limit of $10 \%$, their marketable rate, which must be higher than $75 \%$ of the treated batch fruits, etc.

Fruits treated on the harvesting day often present damage on the surface. On the other hand, if they are treated ( 24 to 48 ) $\mathrm{h}$ after harvesting, these disadvantages are reduced.

\subsubsection{Fruit cooling after warm-water treatment}

Fruit cooling after the warm-water treatment is not an obligation required by the treatment technique registration authorities. However, many factories install a cooling system to treat fruits when they exit the warm water

In order to improve the effectiveness of the warm-water treatment on larva mortality, the treated fruits should not be transferred into a cooled room during the $30 \mathrm{~min}$ which follow the treatment.
For mangos, the recommended cooling temperature is $12.8{ }^{\circ} \mathrm{C}$ with $85-90 \%$ of relative humidity. These parameters would make it possible to slow down the fruit softening and to increase its shelf life by 2 to 3 weeks.

The fruit cooling can be carried out by ventilators or hydrocooling:

- Ventilator use can be authorized for fruit sweeping after exiting the warm-water tanks; the ambient air temperature must be lower than $21.1^{\circ} \mathrm{C}$.

- Hydrocooling, by immersion or sprinkling, can be considered but, as previously explained, it must be carried out $30 \mathrm{~min}$ after the fruit heat treatment. Between these two periods of treatment, mangos, for example, must be stored in a room or a tunnel separate from the warm-water tanks. During the hydrocooling, the water temperature is not controlled; on the other hand, the temperature used must not be too cold because that could involve damage on the fruit surface.

According to the producer countries, destinations and fruits concerned, the treatment methods can differ (figures 1-4).

\subsection{Hot-air treatment}

Vapor heat treatments and high-temperature forced air are virtually identical: nevertheless, in the vapor phase, water condenses on the fruit surface whereas, in high-temperature forced air, it remains dry.

\subsubsection{Vapor heat treatment}

Vapor heat treatment (VHT) is also called heating by air with high moisture.

To bring the fruits which must be treated to the desired temperature, during a determined period which is specific according to the insect to eliminate, the VHT uses vaporsaturated hot air. In this case, the increase in temperature is achieved thanks to the latent heat released during the vapor condensation on the skin, then on the fruit pulp.

In this type of process, just as for warm water, the time-temperature couple varies according to the treated fruit and to the pest 


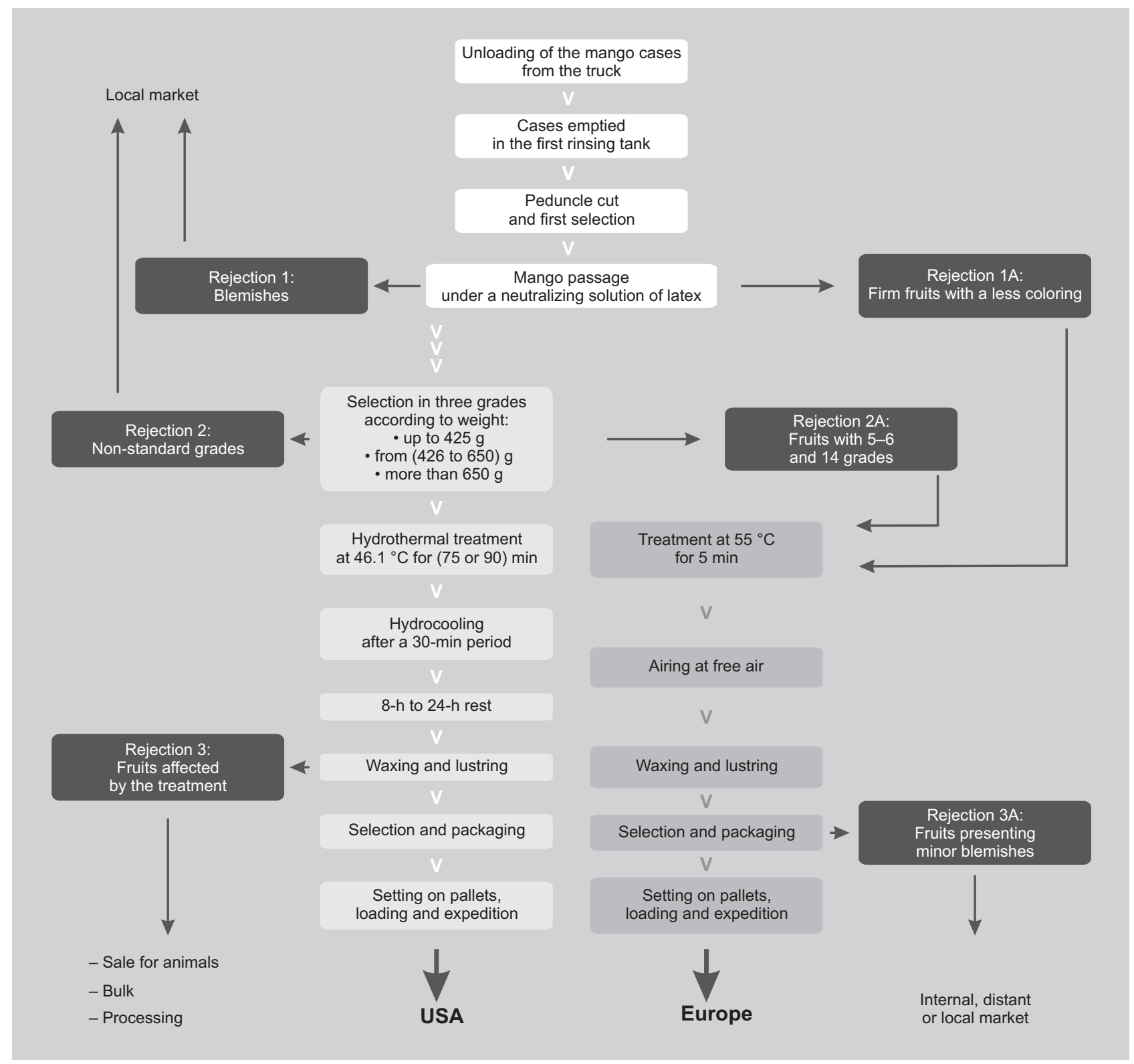

which has to be eliminated. Generally, the temperature of the fruit pulp is raised to $43,3{ }^{\circ} \mathrm{C}-44,4^{\circ} \mathrm{C}$ during a (6 to 8 )-h period; it is then maintained at that temperature during an additional (6 to 8 ) h. Fruits are immediately cooled after treatment. Shorter times can be applied for cut flowers or foliage.

Vapor heat treatment is approved by the United States Department of Agriculture (USDA) for the importation, inter alia, of mangos from Mexico, as well as other products likely infested by the Eastern Mediterranean fly or by the melon fly.

Quarantine treatments, carried out with vapor, are used for exports of Philippines', Thailand's, and Hawaii's mangos to Japan: - Protocols required by the Japanese market include a $46{ }^{\circ} \mathrm{C}$ treatment in the fruit heart for $10 \mathrm{~min}$ for the Carabao mango of the Philippines; $46.5^{\circ} \mathrm{C}$ for $30 \mathrm{~min}$ for the
Figure 2.

Diagram of a packaging system including a warm-water treatment (Brazil, according to C. Arnaud, CIRAD). 
Figure 3.

Traditional system of warmwater treatment for papaws in Malaysia (according to $\mathrm{C}$. Didier, CIRAD).
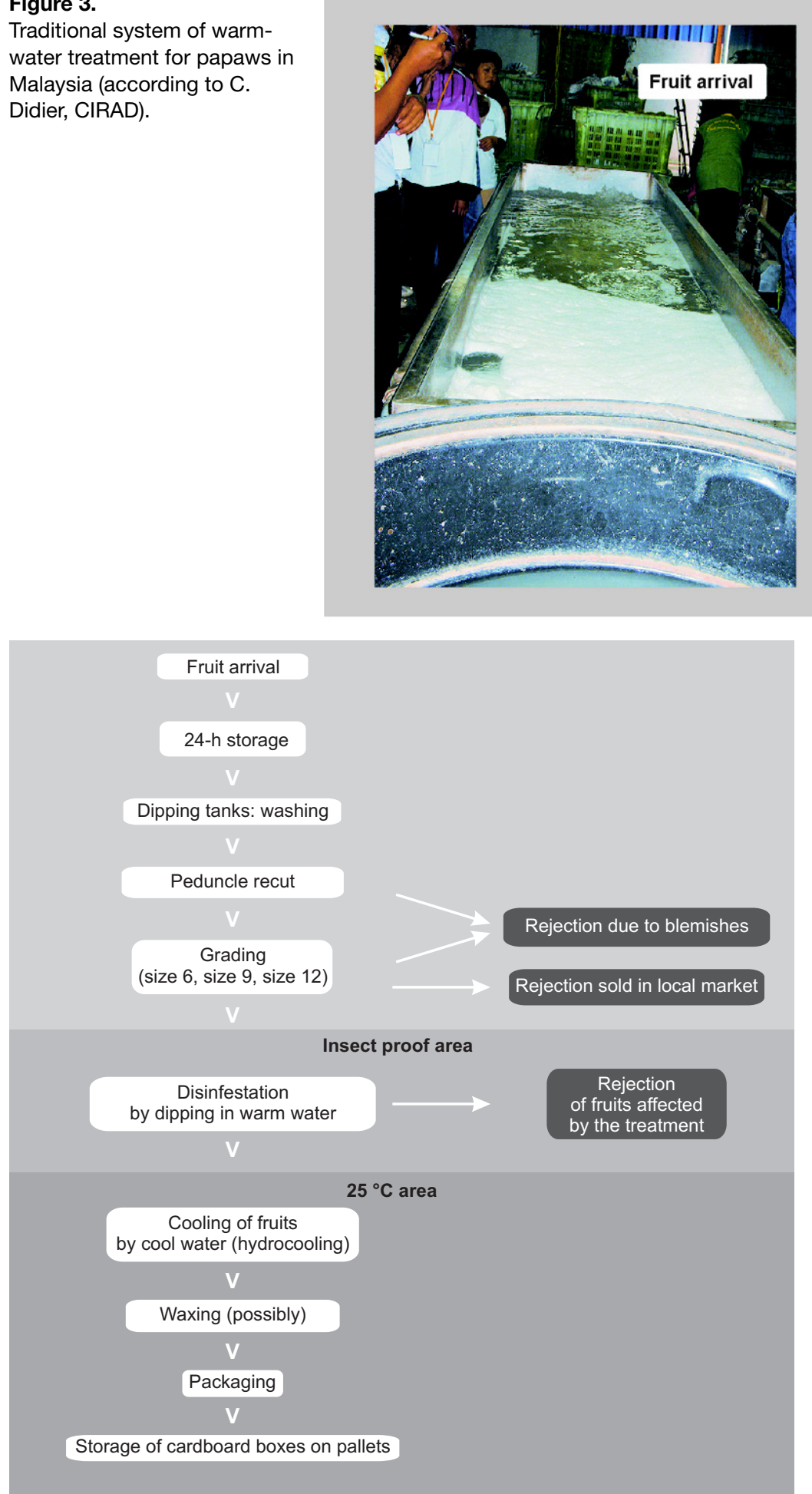

Figure 4.

Chain including the disinsectization warm-water treatment for mangos in Brazil for export to the United States.

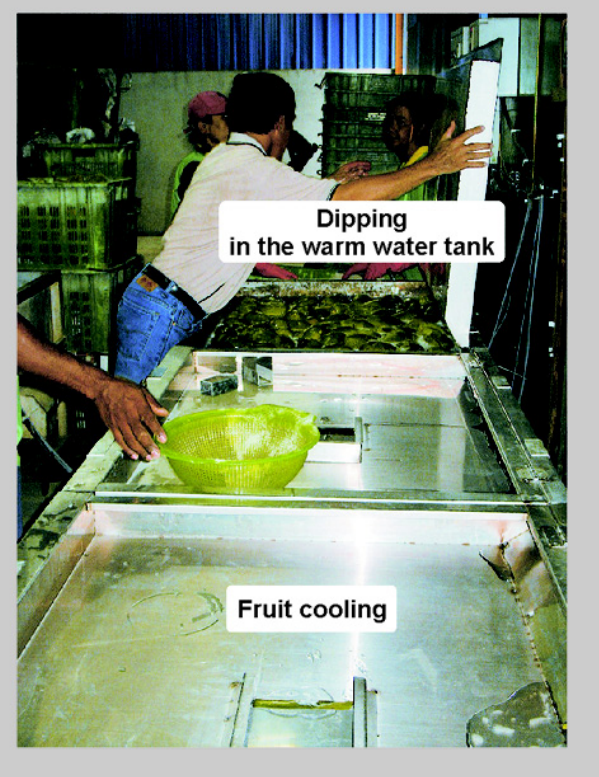

Irwin and Haden mangos from Thailand; $46.5^{\circ} \mathrm{C}$ for $10 \mathrm{~min}$ for the Nang Klang Wun mango of Thailand; and $47^{\circ} \mathrm{C}$ for $10 \mathrm{~min}$ for the Nam Doc Mai, Pimsen Dang and Rad mangos.

- The protocol accepted by Japan for the admission of the Australian Kensington variety fruits requires a temperature of $47^{\circ} \mathrm{C}$ in the fruit heart for $15 \mathrm{~min}$.

- In the USA, the Mexican Manila variety mango is authorized to enter only after a treatment at $43.3^{\circ} \mathrm{C}$ for $6 \mathrm{~h}$.

It is noted that each variety, each origin and each pest involves a modification of the treatment protocols.

\subsubsection{Forced-air treatment}

For this postharvest type of treatment, a heated and humidified air is forced to circulate through fruits in order to increase the temperature to a lethal level for the pests which must be killed. Use of air heated between ( 40 and 50$)^{\circ} \mathrm{C}$, in general by means of four increasing temperatures and for less than $8 \mathrm{~h}$, has become a usual control for fruit fly of the tropical species [9, 15-22].

Accurate control of the temperature and relative humidity has many advantages because it prevents having condensation in the treatment areas and on the fruit surface, 
which makes it possible to prevent fruit desiccation and scald [18].

Fruits which tolerate forced-air treatment are carambolas [22], mangos [19, 22, 23], navel oranges [24], papaws [16] and pomelos $[9,13,21]$. On the other hand, this treatment is not recommended for avocados, litchis or nectarines [20]. Forced-air treatment is approved by the USA for mangos, papaws and pomelos.

The flies concerned with forced-air treatment are:

- for mangos from Mexico City: the Mexican fly (Anastrepha ludens), the WestIndies fly (Anastrepha obliqued) and the black fly (Rhagoletis ribicola);

- for pomelos from Mexico City: the Mexican fly;

- for papaws from Hawaii: the Mediterranean fruit fly (Ceratitis capitata), the oriental fruit fly (Bactrocera dorsalis) and the melon fruit fly (Bactrocera cucurbita) [1].

Forced-air treatments are used for the export of Hawaiian papaws to the USA and for papaws from the Cook Islands to New Zealand (figure 5).

\subsection{In short...}

Warm-water and vapor heat treatments are usually used on mangos. They control pests well. However, certain problems can appear on the skin depending on the treated fruits, their maturity, their size and thermal conductibility; thus, special attention must be paid to these types of treatment, which, in addition, can accelerate the fruit maturation, in certain cases; this is strongly inadvisable for their transport (table II).

These heat treatment techniques, by immersion or vapor, and the ambient parameters must be very strictly controlled, which often poses problems for their implementation. The necessary installations, which are expensive, can, however, be offset by other uses.

\section{Microwave treatments}

Energy generated by the waves corresponding to radio frequencies is not initially heat;

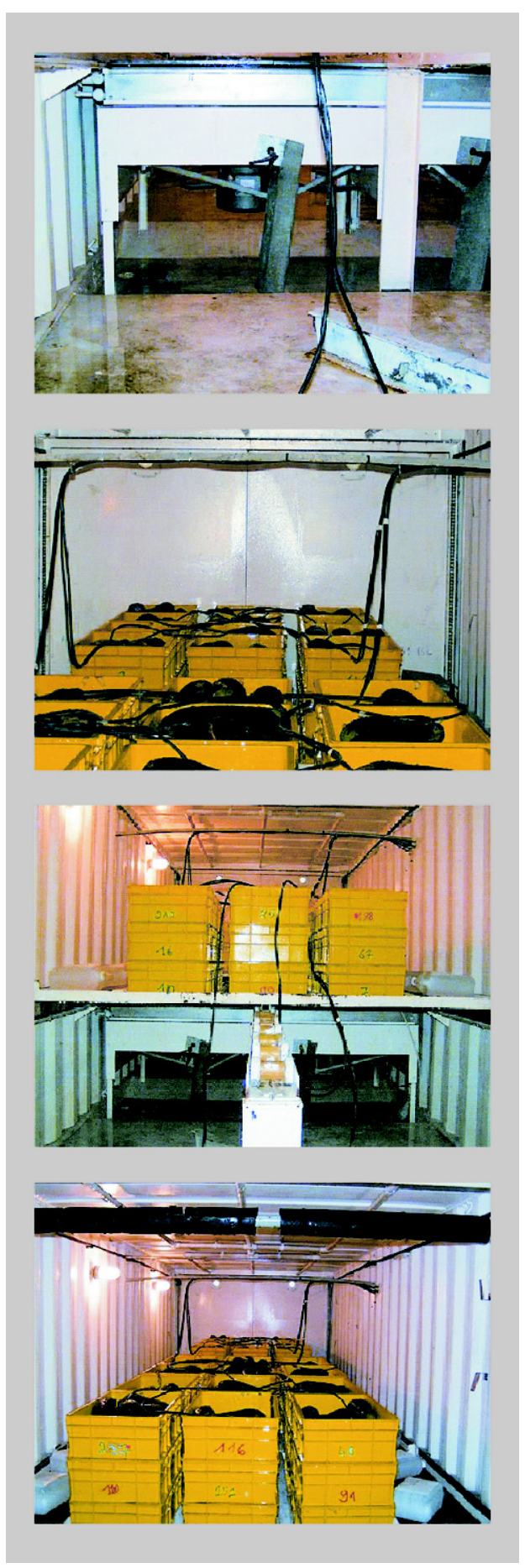

Figure 5.

Blast hot-air treatment: interior of the hot-air treatment box set up at the Tontouta airport, Noumea, New Caledonia (according to V. Kagy, IAC, New Caledonia). in fact, microwaves used in the electromagnetic energy spectrum of $10 \mathrm{kHz}$ to $100 \mathrm{GHz}$ are used to heat products by conversion of electromagnetic energy into calorific energy. 


\begin{tabular}{|c|c|c|c|}
\hline Cultivar & Heat treatment & Ripening response & Reference \\
\hline Carabao & VHT $46{ }^{\circ} \mathrm{C}$ for $10 \mathrm{~min}$ & Increased respiration rate, yellowing of skin & [39] \\
\hline Keitt & HWT $46.1-46.7^{\circ} \mathrm{C}$ for (20 to 60 ) min & Yellowing of skin, uniformity of color & [41] \\
\hline Keitt, Palmer, Tommy Atkins & $\begin{array}{l}\text { FHAT } 466^{\circ} \mathrm{C} \text { for } 3.25 \mathrm{~h} \\
\text { or FHAT } 48^{\circ} \mathrm{C} \text { for } 2.5 \mathrm{~h} \\
\text { or HWT } 44^{\circ} \mathrm{C} \text { core for } 25 \mathrm{~min}\end{array}$ & $\begin{array}{l}\text { Yellowing of skin, uniformity of color, } \\
\text { fruit softening }\end{array}$ & [14] \\
\hline \multirow[t]{3}{*}{ Keitt, Tommy Atkins } & $\begin{array}{l}\text { HWT } 46^{\circ} \mathrm{C} \text { for }(60 \text { to } 120) \text { min } \\
\text { or HWT } 49^{\circ} \mathrm{C} \text { for } 60 \mathrm{~min}\end{array}$ & Yellowing of skin & [34] \\
\hline & $\begin{array}{l}\text { FHAT } 46^{\circ} \mathrm{C} \text { for }(3 \text { to } 4) \mathrm{h} \\
\text { or FHAT } 48^{\circ} \mathrm{C} \text { for } 5 \mathrm{~h}\end{array}$ & Increased respiration rate & [38] \\
\hline & Conditioning $38^{\circ} \mathrm{C}$ for $48 \mathrm{~h}$ & Yellowing of skin & [40] \\
\hline Kensington & $\begin{array}{l}\text { VHT and HWT } 47^{\circ} \mathrm{C} \text { for ( }(7.5 \text { to } 30) \mathrm{min} \\
\text { or VHT } 46.5^{\circ} \mathrm{C} \text { for } 10 \mathrm{~min} \\
\text { or VHT } 47^{\circ} \mathrm{C} \text { for } 15 \mathrm{~min}\end{array}$ & $\begin{array}{l}\text { Yellowing of skin, uniformity of color, } \\
\text { fruit softening }\end{array}$ & {$[35,42]$} \\
\hline Tommy Atkins & FHAT $51.5^{\circ} \mathrm{C}$ for $125 \mathrm{~min}$ & Fruit softening & [23] \\
\hline
\end{tabular}

Conventional heating methods using air and water allow an increase in the temperature of the skin towards the product's heart, but they are slow compared with microwave techniques. The microwave energy on spherical products is focused towards the product's center and the maximum concentration is reached when the penetration thickness is approximately equal to 1.5 times the product diameter. The heating rate can be controlled; it depends on the type of material used and the treated product.

Studies using microwaves were done to try to destroy certain mango parasites (Cryptorbynchus mangiferae) [25]. They prove that fruits are damaged by the generated temperatures: a temperature of $63{ }^{\circ} \mathrm{C}$ involves a parasite mortality of $87 \%$. With an intermittent treatment of (10 to 15) s instead of a continuous treatment longer than $60 \mathrm{~s}$, damage is decreased, but not completely removed.

To try to improve the treatment effectiveness, probes were distributed in fruits of the Kent mature green mango: one of them was placed in the stone's center, another on the stone's surface and a third midway between the skin and the stone. Certain physical characteristics were measured; the results were the following: fruit weight, $(535.2 \pm$ 11.8) g; distance between the skin's surface and the stone's center, $(40.7 \pm 6.8) \mathrm{mm}$; distance between the skin's surface and the stone, $(30.7 \pm 5.2) \mathrm{mm}$ and half of the distance between the skin and the stone's surface, $(15.3 \pm 3.6) \mathrm{mm}$.

As the heating evolves from the fruit's surface towards its center, Cryptorbinchus mangiferae larvae, present in the mango stone, are difficult to control with the conventional systems previously described (hot air, vapor heat or dipping into warm water). Indeed, before reaching $48^{\circ} \mathrm{C}$ in the stone's center, the fruit pulp can suffer severe damage because of its exposure to a too strong heat. On the other hand, microwave use makes it possible for the stone to reach this lethal temperature for the larvae, before the other fruit parts are deteriorated by too strong temperatures. Parasites present inside the stone are thus killed and the damage to the pulp is reduced. The microwave technique is also effective against Bephratellö̈es cubensis. Because this weevil is present in West Africa, research on the microwave treatment effectiveness would be particularly interesting in order to control this parasite, and for the setting up of the quarantine processes. 
In spite of very optimistic beginnings in product disinfestation by the use of microwave heat, this process is still not commercially used because of its cost in energy, the nonhomogeneous heating of tissues and the damage generated to the products [26]. A better comprehension of the operating process of the heating system by microwaves could be useful to progress with the use of this technology in the quarantine systems.

Microwave use on fresh material currently presents application problems; studies should be undertaken to test different wavelengths, intermittent exposures and the concomitant use of microwaves with other techniques to perfect a quarantine treatment [25]. However, this system was patented for the disinfestation of dates [27]. The concomitant use of two treatment techniques has a synergy effect which involves a pest mortality higher than that observed with the addition of two individual treatments. In addition, tests were realized by using gamma irradiations coupled to microwaves [28].

\section{Irradiation}

Irradiations with $\mathrm{X}$ - and gamma rays are used in quarantine treatment against fruit fly (Tephritidae).

Research carried out in Hawaii showed that a (15 to 100) krad gamma irradiation made it possible to treat many fruits and vegetables infested by the Mediterranean fly [29].

Many countries accept foodstuff irradiations and, in particular, fruit irradiation. The Food and Drug Administration of the United States (US-FDA) accepts this quarantine treatment of fresh fruits provided that it does not exceed a rate of $1 \mathrm{kGy}$ [30].

The majority of the installations allowing treatments by irradiation use radioactive isotope sources, such as cobalt or cesium. Other systems such as electron accelerators can be employed; the energy rate is identical to that of the cobalt or cesium sources, but this system covers a much broader photonic energy band, which causes a more homogeneous irradiation of the products. Moreover, contrary to the radioactive sources, there are then no problems when the machine is stopped.

This kind of quarantine use remains subject to certain reserves:

- studies must be undertaken to check that the treatment does not degrade the fruit quality;

- the system profitability must be checked because it requires a very strict installation and maintenance;

- the purchase acceptance, by the consumer, of irradiated products must finally be tested.

If the answers to these various questions were positive, this quarantine treatment against fruit fly would be completely possible [31].

Currently, this technique is being commercially tested in the USA on papaws from Hawaii, litchis and other tropical fruits to see whether product irradiation can be developed in quarantine treatment.

It should be noted that there exists a very strict regulation for marking of products treated by irradiation, which must inform the consumer. The consumer could therefore strongly reject this type of treatment which, in addition, has an extremely high cost.

\section{Conclusion}

In comparison with the most usual treatments (vapor heat treatment and forced hotair treatment), the treatment by warm-water immersion has many advantages:

- it is relatively easy to implement in the packaging stations;

- the treatment time is short; it can be connected and controlled by both the fruit level and the water temperature;

- it has the advantage of destroying surface parasitic organisms, generators of postharvest losses;

- it makes it possible to clean the fruit surface (exudate suppression, for example); 
- its cost only corresponds to approximately $10 \%$ of the cost of one vapor heat treatment [32].

Thus, treatment by warm-water steeping would be recommended for mango disinfestation.

\section{References}

[1] Anon., T103-High temperature forced air, Plant protection and quarantine treatment manual, Animal and plant health inspection service, USDA, Hyattsville MD, USA, 1996, pp. 5.51-5.53.

[2] Gould W.P., Sharp J.L., High temperature forced air research facility for heating fruits for insect quarantine treatments, J. Econ. Entomol. 83 (1990) 458-460.

[3] Gould W.P., Sharp J.L., Hot water immersion quarantine treatment for guavas infested with Caribbean fruit fly (Dipthera: Tephritidae), J. Econ. Entomol. 85 (1992) 12351239.

[4] Hallman G.J., Sharp J.L., Quarantine treatments for pests of food plants, Westview Press, Boulder, Colorado, USA, 1994.

[5] Sharp J.L., Hot-water treatment for contro of Anastrepha suspensa (Diptera: Tephritidae) in mangoes, J. Econ. Entomol. 79 (1986) 706-708.

[6] Sharp J.L., Hot-water immersion appliance for quarantine research, J. Econ. Entomol. 82 (1989) 189-192.

[7] Sharp J.L., Picho-Martinez H., Hot-water as a quarantine treatment to control fruit flies in mangoes imported into the United States from Peru, J. Econ. Entomol. 83 (1990) 1940-1943.

[8] Sharp J.L., Ouye M.T., Hart W., Ingle S., Chew V., Submersion of 'Francis' mango in hot water as a quarantine treatment for the West Indian fruit fly (Diptera: Tephritidae), J. Econ. Entomol. 81(1988) 1431-1436.

[9] Sharp J.L., Ouye M.T., Hart W., Ingle S., Hallman G., Gould W., Chew V., Immersion of Florida mangos in hot water as a quarantine treatment for Caribbean fruit fly (Diptera: Tephritidae), J. Econ. Entomol. 82 (1989) 186-188.

[10] Sharp J.L., Ouye M.T., Ingle S.J., Hart W.G., Hot-water quarantine treatment for mangoes from Mexico infested with Mexican fruit fly and West Indian fruit fly (Diptera: Tephritidae). J. Econ. Entomol. 82 (1989) 16571662.

[11] Sharp J.L., Ouye M.T., Ingle S.J., Hart W.G., Enkerlin H.W.R., Celedonio H.H., Toledo A. J., Stevens L., Quintero E., Reyes F., Schwarz A., Hot-water quarantine treatment for mangoes from the State of Chiapas, Mexico, infested with Mediterranean fruit fly and Artastrepha serpentina (Wiedemann) (Diptera: Tephritidae), J. Econ. Entomol. 82 (1989) 1663-1666.

[12] Sharp L., Spalding D.H., Hot water as a quarantine treatment for Florida mangoes infested with Caribbean fruit fly, Proc. Fla. State Hortic. Soc. 97 (1984) 355-357.

[13] McGuire R.G., Concomitant decay réductions when mangoes are treated with heat to control infestations of Caribbean fruit flies, Plant Dis. 75 (1991) 946-949.

[14] Couey H.M., Heat treatment for control of postharvest disease and insect pests of fruit, HortScience 24 (1989) 198-202.

[15] Armstrong J.W., Couey H.M., Fruit flies, their biology, natural enemies, and control, in: World crop pests, Vol. 3A, Elsevier, Rotterdam, Netherlands, 1989.

[16] Armstrong J.W., Hansen J.D., Hu B.K.S., Brown S.A., High-temperature, forced-air quarantine treatment for papayas infested with Tephritid fruit flies (Diptera: Tephritidae), J. Econ. Entomol. 82 (1989) 1667-1674.

[17] Armstrong J.W, Hansen J.D., Hu B.K.S., Brown S.A., Patent seria No. 07/270/608, issued March 11, Australia, 1989.

[18] Gaffney J.J., Armstrong J.W., High-temperature forced air research facility for heating fruits for insect quarantine treatments, J. Econ. Entomol. 83 (1990) 1959-1964.

[19] Mangan R.L., Ingle S.J., Forced hot-air quarantine treatment for mangoes infested with West Indian fruit fly (Diptera: Tephritidae), J. Econ. Entomol. 85 (1992) 1859-1864.

[20] Sharp J.L., Hot-air alternative quarantine treatment for methyl bromide fumigation to disinfest fruits, In: Proc. Annu. Int. Res. Conf. Methyl Bromide Alternat. Emission Reduct., Nov. 13-16, 1994, Methyl Bromide Alternatives Outreach, Orlando, FL, USA, pp. 65-165-6.

[21] Sharp J.L., Gould W.P., Control of Caribbean fruit fly (Diptera: Tephritidae) in grapefruit by 
forced hot air and hydrocooling, J. Econ. Entomol. 87 (1994) 131-133.

[22] Sharp J.L., Hallman G.J., Hot air quarantine treatment for carambolas infested with Caribbean fruit fly (Diptera: Tephritidae), J. Econ. Entomol. 85 (1992) 168-171.

[23] Miller W.R., McDonald R.E., Sharp. J.L., Quality changes during storage and ripening of 'Tommy Atkins' mangos treated with heated forced air, HortScience 26 (1991) 395-397.

[24] Sharp J.L., Microwave quarantine treatment for tropical fruits, Int. Conf. Trop. Fruits, Mardi, Kuala Lumpur, Malaysia, 1996.

[25] Seo S.T., Chambers D.L., Komura M., Lee C.Y.L., Mortality of mango weevils in mangoes treated by dielectric heating, J. Econ. Entomol. 63 (1970) 1977-1978.

[26] Amstrong J.W., Fruit fly disinfestation strategies beyond methyl bromide, New Zealand J. Crop Hortic. Sci. 20 (1992) 181-193.

[27] Reynes M., Procédé et dispositif de désinsectisation de fruits, Brev. INPI, numéro dépôt 230214, numéro publ. 20207, 30 novembre 1997.

[28] Tilton E.W, Brower J.H., Brown G.A., Kirkpatrick R.L., Combination of gamma and microwave radiation for control of the Angoumois grain moth in wheat, J. Econ. Entomol. 65 (1972) 531-533.

[29] Seo S.T., Kobayashi R.M., Chambers D.L., Dollar A.M., Hanaoka M., Hawaiian fruit flies in papaya, bell peper, and egg plant: quarantine treatment with gamma irradiation, J. Econ. Entomol. 66 (1973) 937-939.

[30] Anon., Irradiation in the production, processing and handling of food. Final rule, Congr. Fed. Regist. 51, Wash. D.C., US Gov. Print. Off., 1986, 13376.

[31] Maxie E.C., Sommer N.F., Mitchell F.G., Infeasibility of irradiating fresh fruits and vegetables, Hortscience 6 (1971) 202-204.

[32] Jordan R.A., The disinfestation heat treatment process. Plant quarantine in Asia and the Pacific, Asian Product. Organ., Tokyo, Japan, 1993, pp. 53-68.
[33] Jacobi K.K, Mac Rae E.A., Hetherington S.E., Postharvest disinfestation treatments of mango fruit, Sci. Hortic. 89 (2001) 171173.

[34] Spalding D.H., King J.R., Sharp J.L., Quality and decay of mangos treated with hot water for quarantine control of fruit fly, Trop. Sci. 28 (1988) 95-101.

[35] Jacobi K.K., Wong L.S., Quality of Kensington mango (Mangifera indica L.) following hot water and vapour-heat treatments, Postharvest Biol. Technol. 1 (1992) 349359.

[36] Smith E.S.C., Chin D., Hot water dipping as a disinfestation treatment against the fruit fly Docus aguilottis (May) (Diptera: Tephritidae) in mangoes, Acta Hortic. 291 (1989) 389-403.

[37] Joyce D.C., Hockings P.D., Mazucco R.A., Shorter A.J., Brereton L.M., Heat treatment injury of mango fruit revealed by nondestructive magnetic resonance imaging, Postharvest Biol. Technol. 3 (1993) 305311.

[38] Mitcham F.J., Mc Donald R.E., Respiration rate, internal atmosphere, and ethanol and acetaldehyde accumulation in heat-treated mango fruit, Postharvest Biol. Technol. 3 (1993) 77-86.

[39] Esguerra E.B., Lizada M.C.C., The postharvest behaviour and quality of 'Carabao' mangoes subjected to vapor heat treatment, ASEAN Food J. 5 (1990) 6-11.

[40] Pesis E., Faure M., Marinansky-Ben Arie R., Induction of chilling tolerance in mango by temperature conditioning, heat, low $\mathrm{O}_{2}$ and ethanol vapours, Acta Hortic. 455 (1997) 629-634.

[41] Segarra Carmona A.E., Franqui R.A., Ramirez-Ramos L.V., Santiago L.R., TorresRivera C.N., Hot water dip treatments to destroy Anastrepha obliqua larvae (Diptera: Tephritidae) in mangoes from Puerto Rico, J. Agric. Univ. Puerto Rico 74 (1990) 441-447.

[42] Jacobi K., Giles J., MacRae E., Wegrzyn T., Conditioning 'Kensington' mango with hot air alleviates hot water disinfestation injuries, HortScience 30 (1995) 562-565. 
Mosca de las frutas: desinfectación, técnicas empleadas, posible aplicación en el mango.

Resumen - Introducción. Los métodos de desinfectación de las frutas para las infestaciones de moscas de frutas exigen procedimientos (métodos físicos) que difieren según el país de exportación y según el fruto que debe ser desinsectizado. A continuación se retoman las definiciones de los términos y se presentan los diferentes tratamientos. Tratamientos mediante calor. Para el mango, los tratamientos empleados para la desinsectación permiten únicamente que intervenga el calor, debido a la fuerte sensibilidad que posee este fruto al frío. Los tratamientos mediante calor consisten por lo general en utilizar una inmersión en agua caliente mediante sistema de cargas sucesivas o de cargas en continuo. Estos tratamientos pueden ser sucedidos o no por un rápido enfriamiento de los frutos, el cual se puede realizar mediante ventilación (aire frío), o mediante bydrocooling (agua). Puede obtenerse también el calor mediante el uso de aire caliente forzado o de vapor caliente, ya que una temperatura superior a $45^{\circ} \mathrm{C}$ mata los huevos y las larvas de las moscas. Tratamientos mediante micro-ondas. El uso de micro-ondas representa asimismo una técnica que permite aumentar la temperatura desde el corazón del fruto. Irradiación. La última solución planteable es la utilización de la irradiación, que pone en juego un principio diferente al de los anteriores. Conclusión. En comparación con los tratamientos más corrientes (tratamiento mediante vapor de agua caliente y tratamiento mediante aire caliente forzado), el tratamiento mediante sumersión en agua caliente posee numerosas ventajas: es fácil de poner en obra, dura poco, destruye los organismos parásitos de superficie, permite limpiar la superficie de los frutos y su coste corresponde aproximadamente a tan sólo el 10\% del coste de un tratamiento mediante vapor de agua caliente. Por ello se preconiza para la desinfestación de los mangos.

Francia / frutas / Mangífera índica / tephritidae / control de plagas / calor 